\title{
Electricity Services Always in the Making: Informality and the Work of Infrastructure Maintenance and Repair in an African City
}

\author{
Idalina Baptista \\ Associate Professor in Urban Anthropology \\ University of Oxford
}

\begin{abstract}
Access to 'formal' electricity networks remains a key challenge in many African urban areas. Significant attention has been paid to how access to an electricity connection should be provided, with much less attention paid to how electricity infrastructures are operated and maintained. Attention to how utilities govern the challenges inherent to 'informality' in the production of 'formal' networked infrastructure is less common, especially in African cities. Moreover, with a few notable exceptions, studies on infrastructure maintenance and repair treat 'informality' as a subtext to broader examinations of the uneven urban landscapes produced through infrastructures and its mediating technologies.

Drawing on a socio-technical approach to electricity infrastructures, this article explores how utilities engage with 'informality' to produce access to 'formal' electricity networks through everyday processes of maintenance and repair. To this end, the article uses the empirical case of Mozambique's national electricity company, EDM (Electricidade de Moçambique, E.P.) and its transition to an electricity network mediated by prepayment technologies in the capital city Maputo. The article argues that a socio-technical approach to infrastructures provides key insights into how utilities implicate the spatial and socio-economic dimensions of 'informality' in the design, delivery, and maintenance and repair of 'formal' electricity networks. They do so through pragmatic, situated practices that sustain and continuously produce and reproduce infrastructures in cities. This highlights how infrastructures are always 'precarious achievements' and service delivery always a process in the making. The article is based on deskwork, archival work, and fieldwork conducted by the author in Maputo since 2013.
\end{abstract}

\section{Keywords}

Urbanization and developing countries, Informality, Infrastructure, Prepayment, Sociotechnical approach 


\section{Introduction}

Access to 'formal' electricity networks remains a key challenge in many African urban areas. This is particularly the case in contexts of 'informality', ${ }^{1}$ where socio-economic conditions and the nature of the built environment have long defied the provision and operation of conventional electricity networks (Coutard, 2008; Coutard and Rutherford, 2016; Monstadt and Schramm, 2017). As such, significant attention has been paid to how access to an electricity connection should be provided (i.e. on-grid, off-grid or hybrid solutions), with much less attention paid to how said infrastructures are operated and maintained (Baptista and Plananska, 2017). Yet, maintenance and repair is key to sustaining service delivery over time, especially in contexts of informality.

Urban research inspired by a socio-technical approach to infrastructure has brought attention to maintenance and repair as key to the constitution of service delivery (e.g. Graham and Thrift, 2007). Research focusing on cities of the global South emphasizes the everyday processes through which users produce, maintain, and contest 'formal' and 'informal' infrastructures (McFarlane et al., 2014; Pilo', 2017). There is growing interest in looking empirically at suppliers as well (e.g. Alda-Vidal et al., 2018; Anand, 2015; Criqui and Zérah, 2015; Criqui, 2015) and at the role of mediating digital technologies enlisted in the operation and management of different urban infrastructures (e.g. Luque-Ayala and Marvin, 2016; Baptista, 2015a; von Schnitzler, 2013). In this work, 'informality' is largely the subtext to broader examinations of the uneven urban landscapes produced through infrastructures and its mediating technologies. Attention to how utilities govern the challenges inherent to 'informality' in the production of 'formal' networked infrastructure is less common, especially in African cities.

Drawing on a socio-technical approach to electricity infrastructures, this article explores how utilities engage with 'informality' to produce access to 'formal' electricity networks through everyday processes of maintenance and repair. To this end, the article uses the empirical case of Mozambique's national electricity company, EDM (Electricidade de Moçambique, E.P.) and its transition to an electricity network mediated by prepayment technologies in the capital city Maputo. The article argues that a socio-technical approach to infrastructures provides key insights into how utilities implicate the spatial and socio-economic dimensions of 'informality' in the design, delivery, and maintenance and repair of 'formal' electricity networks. They do so, the article argues, through pragmatic, situated practices that sustain and continuously produce and reproduce infrastructures in cities. This highlights how infrastructures are always 'precarious achievements' and service delivery always a process in the making. Methodologically, the article draws on deskwork, archival work, and fieldwork undertaken in Maputo since 2013. Throughout this period, I gathered primary data through semi-structured interviews and informal conversations with 157 people, including 42 EDM staff (ranging from directors to field workers), 21 sales assistants and managers at prepayment shops, 60 users of the prepayment system, 17 experts (including donors) on energy, urban development, and local politics, and 11 other informants. The data collected with EDM staff ranged from semistructured interviews to informal conversations during field observation of EDM staff operating in the field and other site visits. Throughout this period, I have also collected

1 This article adopts a rather prosaic (albeit not unproblematic) notion of 'informality' as the physical and immaterial expressions of the built environment in unplanned or irregular settlements, often in socio-economic conditions of poverty, but not exclusively. See section 2 for discussions on notions of 'informality'. 
secondary data in the form of official documentation produced by EDM, donors and local NGOs, as well as archival records and media reports. Data has been analyzed through content analysis, following a qualitative approach as outlined in Berg (2004).

The article is organized in three further sections. Section two (next), begins with an overview of three sets of debates: on the nature of 'informality' and its governance; on a socio-technical approach to infrastructure; and on infrastructure maintenance and repair. The section bringing together these debates to better inform the discussion of the ways in which utilities engage with 'informality'. The third section proceeds with an examination of the empirical case study to illustrate the arguments of the paper. The fourth and final section brings the paper to a conclusion, exploring what its arguments have to offer to the theorization of urban infrastructures in contexts of informality.

\section{Socio-technical approaches to infrastructure and informality}

\subsection{Informality and its governance}

Looking at a glance at the New Urban Agenda approved in Quito, Ecuador in October 2016 (UN-HABITAT, 2017), it is impossible to miss the abundance of references to 'informal' (and 'formal') settlements, economy, etc. What counts as 'informal' or 'formal', however, is a matter of ongoing debates among urban scholars (McFarlane, 2012; Varley, 2013; Hansen and Vaa, 2004). Ontological discussions range from older 'informal' spatial or economic categories outside 'formal' state control that were associated with contexts of poverty in developing countries (Hart, 1973; Turner, 1978; Payne, 1977); ${ }^{2}$ to approaches that seek to move beyond those dualisms - either by assuming a continuum between 'formal' and 'informal' (Bromley, 1978), or by seeing 'informality' as a mode of regulation (Castells and Portes, 1989) or a form of practice (McFarlane, 2012). Roy and AlSayyad (2004) proposed 'urban informality' as a mode of urbanization, "an organizing logic, a system of norms that governs the process of urban transformation itself" (Roy, 2005: 148). Later on, Roy seemed to favor a more epistemological (and methodological) categorization of 'urban informality' by claiming it should be understood as "a heuristic device that uncovers the ever-shifting urban relationship between the legal and illegal, legitimate and illegitimate, authorized and unauthorized" (Roy, 2011: 233). Her approach seems to try to dissociate 'informality' from underdevelopment, poverty, and illegality and, instead, foreground its pervasiveness and shifting quality.

These diverse ways of conceptualizing 'informality' have proved a fertile analytical ground for understanding and criticizing how it is governed. Scholarship abounds on the various ways in which states seek to govern 'informality', ${ }^{3}$ including: through elimination - e.g. slum clearance, squatter evictions, disconnections of illegal/extralegal service connections - often justified by 'othering' narratives of incivility and underserving subjects (see Ghertner, 2012); through normalization - e.g. slum upgrading, land titling, extension of 'formal' service connections - via the formalization of 'pathological' spaces and activities (see Kamete, 2013); or through toleration - e.g. mediated and negotiated access to land, housing, basic urban services, work

2 Dualist 'formal-informal' discussions in the late 1960s/early 1970s on housing in Africa, Latin America, or Southeast Asia referred to a diversity of situations that were variously designated as 'squatter settlements', 'illegal settlements', 'self-help housing'. The term 'slum' had been abandoned by then, given its pejorative and ideological connotations (see Gilbert, 2007).

3 One of the latest efforts is the edited volume by McFarlane and Waibel (2012). 
and other rights - as means of sustaining power relations and governing logics (see Roy and AlSayyad, 2004). In other words, 'informality' may be governed via strategies that range from more or less benign (or ominous) attempts at 'formalizing' the 'informal' and the more or less intentional perpetuation of 'informality' as a form of structural power or rationality of government. The premise of this continuum is the 'undesirability' of 'informality' and the impetus of attending to it with a view to a more 'desirable' 'formality'.

The debate on the (un)desirability of 'formal'/'informal' infrastructures is key to service delivery in cities of the global South. 'Formal' infrastructures - commonly associated with the 'modern infrastructural ideal' (Graham and Marvin, 2001) of integrated, universal, ubiquitous, and seamless networks - are increasingly under question (Coutard and Rutherford, 2016). Instead of focusing on deviance away from the 'modern infrastructural ideal', some scholars have been studying the 'improvisation', co-existence and co-production of 'formal' and 'informal' services and their value in servicing the poor (Ahlers et al., 2014; Jaglin, 2008; Mitlin, 2008; Silver, 2014). For instance, Jaglin $(2014 ; 2016)$ sees hybrid infrastructures as pragmatic choices in contexts where policy aspirations for a 'formal' networked infrastructure may be an inadequate response to the heterogeneous needs of most users in global South cities. In a similar vein, Furlong (2014) argues that universalization of the ('formal') networked model may not even be a desirable option to many users. Drawing on her work on water services, she notes that users may seek system coexistence "in order to maintain independence, control costs, and limit piped water consumption" (Furlong, 2014: 141). In both Jaglin's and Furlong's work, service solutions are thought as situated, context-specific and relationally co-constituted with the environment in which they operate. These are some of the key features of a sociotechnical approach to urban infrastructures, to which I turn next.

\subsection{Socio-technical approaches: Infrastructure and informality}

Socio-technical approaches conceptualize infrastructures as more than just an inert, taken-forgranted substrate upon which social life unfolds (Star, 1999). Instead, infrastructures can be conceived as complex large socio-technical systems (Hughes, 2012) that are born out of, and shaped by, the context in which they operate and which they also help produce. Thinking specifically about electricity infrastructures, these are deeply intertwined with how societies work and are spatially, materially, institutionally, and politically organized (Bridge et al., 2013). Therefore, the ways in which electricity infrastructures are made available, to whom and where, raise questions of justice and ethics (Sovacool and Dworkin, 2015). Moreover, electricity users are more than rational economic actors balancing costs and benefits (Lutzenhiser, 1993). Social values of status, comfort and convenience, produced and reproduced through everyday social practices, imbue electricity consumption (Shove and Walker, 2014). In sum, a socio-technical approach to electricity infrastructures emphasizes their relational co-constitution through/with space, various combinations of actors, and diverse rationalities.

A socio-technical approach to infrastructure provides useful insights into the ways utilities engage with the environments they operate in, particularly in contexts of 'informality', when planning for and delivering their services. Monstadt and Schramm (2017) have shown that, in the case of water and sanitation services in Dar es Salaam, Tanzania, there is often a mismatch between plans and deeds. They argue that while 'formal' plans keep aspirations towards the 'modern infrastructure ideal', the practice of delivering the service itself requires considerable creativity in the translation of the ideal in into situated, context-specific alternative 
arrangements (ibid.). In a similar vein, Criqui and Zérah (2015; see also Criqui, 2015) have shown that electricity utilities in India and Peru are not prevented from extending their 'formal' networks to unplanned settlements of low-income users. Instead, utilities respond to the material and socio-economic conditions in poorer and unplanned neighborhoods through sociotechnical or institutional bricolage to craft alternative service arrangements (ibid.).

These empirical findings lend support to conceptual insights that, following Hughes (2012: 47), infrastructures are designed, rolled out and governed is a sort of 'problem-solving' way that is "usually concerned with the reordering of the material world to make it more productive of goods and services". These insights share with Callon (2012) a view that when engineers design a new infrastructure and associated technologies they develop hypotheses about how the various parts of the system will act, connect and interact, and about what kind of socioeconomic, cultural, political or physical environment the technology will operate in. These hypotheses are inherently political, because they make value and moral judgments about who the users are and about how they behave and should behave (Winner, 1980; Akrich, 1992).

By the same token, the technological devices utilities adopt to enhance their services (e.g. the prepayment meters analyzed below) are part and parcel of such 'problem-solving' strategies. Viewed as 'mediating technologies' (Furlong, 2010), such devices are usually deployed with specific intents in mind. In fact, prepayment meters had long been a technological solution used in Victorian Britain to 'problem-solve' the issue of electricity theft when connecting poor households to the electricity network (Gooday, 2004). In the late 1980s/early 1990s, South African engineers associated with the national utility Eskom adapted and expanded prepayment technology to address the challenges they faced in the electrification of townships after the end of Apartheid. Acknowledging the scale of economic and material poverty in townships, the engineers saw prepayment as "the technical solution to ensuring payment" (Bezuidenhoudt et al., 1996: 94). They deemed this 'technical solution' adequate for contexts of 'informality' where "the lack of infrastructure - telecommunications and postal, and the informal nature of many of the areas to be electrified, meant that the delivery of bills was impractical" (Bezuidenhoudt et al., 1996: 94). They did acknowledge that prepaid meters were deployed with a view to curtailing electricity theft, but that this remained a technically difficult issue (ibid.). In line with this article's empirical findings (section 3), the use of prepayment meters is thus not without problems, as their implementation can give rise to unanticipated and unintended effects that affect the operation and management of service delivery. This is where a socio-technical understanding of infrastructure maintenance and repair becomes helpful.

\subsection{Maintenance and repair: Infrastructures as 'precarious achievements'}

Scholars have paid attention to the work of infrastructure maintenance and repair following breakdown and catastrophic failures, especially as a result of external events (see Graham and Thrift, 2007). Graham and Thrift (2007: 3) argued that maintenance and repair "makes its bid for significance" somewhere "in the space between breakdown and restoration of the practical equilibrium." Similarly, Jackson (2014: 222) noted that repair is the fulcrum of two worlds: a world that seems to be "always-falling-apart" and "a world in constant process of fixing and reinvention, reconfiguring and reassembling into new combinations and new possibilities." However, it is not just external events that lead to disruptions. Infrastructures require constant work of maintenance and repair to avoid decay, reconfiguration or breakdown (Graham and Thrift, 2007). This is because infrastructures are never stable; they are instead "precarious 
achievements" (Domínguez Rubio, 2016: 75): arrangements of heterogeneous elements that require constant re-assemblage. This work has an obvious material dimension: leaky pipes get patched or substituted by new ones; fallen electricity pylons are re-erected and reconnected again; metering devices are refurbished or replaced. It also has social and political dimensions, not least because, as noted earlier, infrastructures are imbued with moral judgments and power relations (Barnes, 2017; Anand, 2012; McFarlane et al., 2014). Therefore, the work of maintenance and repair seeks to secure not only the material integrity and reliability of infrastructures (Denis and Pontille, 2015), but also what is perceived to be the 'normal' order of things (Ureta, 2014). In sum, the work of maintenance and repair is key to how infrastructures are continuously produced and reproduced, materially and symbolically, and sustained over time.

Seen through this socio-technical lens of infrastructure as a 'precarious achievement', service delivery is a process always in the making one that extends well beyond a connection is provided and the good delivered. Thus, the nature of the work of maintenance and repair in sustaining service delivery over time deserves further attention. Jackson (2014: 222) conceptualizes repair as a kind of understated work, constituted by "the subtle acts of care by which order and meaning in complex sociotechnical systems are maintained and transformed." Therefore, experimentation and innovation are inherent to the work of repair and maintenance (see Castán Broto and Bulkeley, 2013). Not unlike the sociotechnical or institutional bricolage that utilities undertake in extending their services to the unplanned settlements mentioned earlier, the work of maintenance and repair is also a form of ad-hoc, pragmatic problem-solving (Strebel, 2011). It requires an embodied assessment of what works and does not work in the re-assemblage of material objects, technological devices, and the complex socio-economic conditions of the urban environments they are a part of. Moreover, there is a temporal dimension to it, which emphasizes the endless, relentless character of the work conducted by users and service providers alike to keep the infrastructure going (AldaVidal et al., 2018; Anand, 2012; McFarlane et al., 2014).

The relentlessness of infrastructure maintenance and repair is the more prominent in contexts of 'informality', where on-the-ground conditions are challenging and resources scant. In these contexts, the limits of the work of maintenance and repair in achieving the stability and reliability of infrastructures are brought to the fore. As the empirical section of this article illustrates (see next), the integrity of service delivery is always only temporary and disruptions to it are always only displaced.

\section{Informality and the prepaid electricity service always in the making}

The vast majority of Maputo's population - 92\% in 2015 (EDM, 2017) - has access to a 'formal' connection to the national electricity network run by the state-owned, national utility EDM (Electricidade de Moçambique, E.P.). Nearly all households with a 'formal' connection do so through a prepaid meter - 95\% in 2015 (ibid.). Prepaid meters were first introduced in 1995, but became more widely available after 2004, when EDM rolled out prepayment to the wider population under the commercial designation 'Credelec' (a portmanteau of the words 'credit' and 'electricity') (Baptista, 2015a). Mozambicans seem to value Credelec for its convenience, the control over consumption and debt it allows, the lifestyle it enables, and because it helps avoiding conflicts with EDM (Baptista, 2015b). Buying prepaid tokens is now fairly easy, although not problem-free (see 3.3): EDM clients can get them at designated shops, through 
mobile wallet services, mobile banking, smartphone apps, on ATMs, and on the Internet. As an EDM staff explained in an interview, clients can now buy electricity 'anytime, everywhere'. In sum, the prepaid electricity network is now Maputo's new 'formal' infrastructure.

This section will look at the way EDM engages with the city's 'informality' to provide continued access to this prepayment-mediated 'formal' electricity network. It begins with an overview of what may count as 'informality' in Maputo (3.1), as a backdrop to understanding the nature of the 'formal' electricity network itself (3.2) and the work of maintenance and repair needed to sustain service delivery on an everyday basis (3.3).

\subsection{Maputo's urban condition}

A newcomer to Maputo can easily fall prey to spatial stereotypes about what counts as 'formal' or 'informal' in the city. They may be tempted to label as 'formal' the grid-like colonial settlement by the waterfront built to European standards; and as 'informal' the settlements that lie to the hinterland of the grid's more or less distinct boundary. The stereotypes are not without connection to the way Mozambicans distinguish between one and the other. Throughout fieldwork, it was common to hear people refer to the old colonial core as the cidade de cimento (the city of cement), or simply cidade (the city), and to what stands outside it as the subúrbios (the suburbs). In colonial times, the cidade was where some $27 \%$ of the city's population lived (largely white settlers and a minority of black, mixed-race, and Asians) (UPP, 1994). The cidade was formally planned by the Portuguese colonial administration following largely a grid system, with brick or concrete buildings, either in single-family houses or in apartment blocks, serviced by the various infrastructure networks, including electricity (see 3.2). It was the center of administrative colonial power, the location of the main health and education facilities, and the center for business and entertainment of the colonial population (see Mendes, 1985). It was also the space of work for the majority black population (c. 73\%, according to UPP (1994)), most of which lived in the subúrbios, the poorly serviced, slum-like neighborhoods outside the cidade, dominated by constructions of caniço (reed) or corrugated iron and wood planks (Morton, 2015). The racial segmentation and material differences between cidade and subúrbios were visible manifestations of an extractive but fragile colonial capitalism (Morton, 2013).

The cidade and the suburrbios have changed dramatically since independence in 1975, further confounding the neat spatial categories of what is 'formal' and 'informal'. The subúrbios expanded significantly outwards, often occupying land without official planning. ${ }^{4}$ Notwithstanding, some new settlements adopted a grid-like layout, as residents attempted to mimic the aesthetics of what they presume a state-sanctioned settlement to look like (see Nielsen, 2011). Long-time residents upgraded and expanded their homes to cement block buildings, even in neighborhoods that remain poorly serviced and partially slum-like. In fact, it is not uncommon to find large walled compounds side-by-side with more modest cement block homes or makeshift dwellings in the subúrbios. Some neighborhoods have undergone upgrading, carving out space for new (sandy, dirt, and only rarely asphalt) roads, water supply systems and the electricity network. The cidade remained the center of state power, of

4 Jenkins (2012) estimated that only $36 \%$ of land under residential use can be considered as 'officially planned' (i.e. with a legally approved plan); another $13 \%$ of land is deemed 'unofficially' planned (i.e. it may have a plan, but this has not been legally approved, or have the involvement of the municipality), whereas the remaining $51 \%$ are considered simply as 'unplanned' (i.e. with no plan). 
services, business and entertainment, even though much of its infrastructure decayed significantly in the period of the civil war (1977-1992) and has struggled to cope with the city's growth since. Investments in new buildings and new infrastructures are evident in the cidade, but it is never clear whether all these developments clearly qualify as 'formal'. As others have argued (e.g. Bertelsen et al., 2014), it is difficult to clearly separate what is 'formal' and 'informal' in Maputo's urban condition.

\subsection{Maputo's electricity system}

Prior to the introduction of prepayment in 1995, Maputo's electricity system operated on the basis of EDM clients being issued a bill for a metered consumption over a given time period. This old 'formal' system was known, and still is to this day, by one simple word - convencional - literally meaning 'conventional', that which is 'normal', ordinary, what is generally done. The pervasive power of the 'modern infrastructure ideal' underlying this designation is brought to sharp relief once we realize how dysfunctional the old 'formal' system was for the vast majority of the population.

Until the early 1990s, Maputo's electricity network had undergone only modest changes and access was limited to the privileged few in the cidade. Just before independence, electricity supply covered a little over $90 \%$ of households in the cidade, while supply to the subúrbios was negligible (ISA-PM, 1972). Access to electricity was then not just geographically limited, but also highly racialized. This pattern of racially fragmented access to electricity in the cidade changed after independence, when the black population occupied the spaces of the settler population. The expansion of the electricity network to the subúrbios and its new settlements had to wait until the end of the civil war in 1992. During that period, the transmission network that supplied Maputo via South Africa became the target of guerrilla attacks and went offline until 1998 (Isaacman and Isaacman, 2013; Baptista, 2016). This prompted significant shortages in the electricity available for supply. As Mozambique's economy deteriorated throughout the 1980s, due to a complex economic and political environment (Hall and Young, 1997), Maputo's network slowly began to decay and breakdown. Anecdotal evidence gathered during fieldwork suggests that many people stopped paying their electricity bills and electricity theft was rife. In this context, EDM had very limited means to sustain an adequate service through its 'conventional' electricity network.

When the civil war ended in 1992 and the country moved towards a more open market economy, EDM faced several challenges to meet electricity demand. Billing, client debt and electricity theft were sticky issues. On the one hand, with little electricity available, unbilled use of electricity threatened the system both technically and financially. Without a sound means of cost recovery, it was difficult for the utility to expand and improve its services in the post civil war reconstruction effort. This meant a political problem, on the other hand. Because EDM is so intricately connected to the state apparatus, a failure of the utility to electrify the country was equivalent to the failure of the state to get Mozambique on the development track. On a more localized level, tensions between the utility and its clients - due to incorrect estimate billing, disconnections for non-payment, and petty corruption involving utility staff were experienced like confrontations between the state and its citizens. In sum, it was vital for EDM - technically, economically, and politically - to address these various difficulties.

Prepayment presented EDM a technological solution to addressing this complex problem, through a direct engagement with Maputo's 'informality', both in terms of socio-economic 
conditions and the nature of the built environment. According to an informant closely involved with EDM's decision to implement prepayment, the idea came partially from contacts with South Africa's Eskom and their experience with prepayment in townships (see example mentioned at the end of section 2.2). Despite the differences between South Africa and Mozambique, EDM adopted Eskom's profiling of poor users and of the 'unruly' urban environment in which it had to operate. In interviews and informal conversations conducted with EDM staff, they often articulated this profiling in the following terms: first, EDM staff argued, its client base is very poor and has limited means to pay for the electricity they use; hence it is better for clients to be provided a means to control their consumption; second, many of these clients live in neighborhoods that are of difficult access, without street names and postal addresses, and with labyrinth-like housing complexes in some cases; this makes it difficult, in EDM's view, to deliver bills and keep track of debtors; and third, the difficult access to the neighborhoods also means that it is difficult for EDM to keep on top of illegal connections and electricity theft. For EDM, these problems can be tackled through prepayment and the digital technology associated with it: clients receive no bills, they just acquire whatever amount of electricity credit they can or want to buy; EDM uses GPS coordinates, not addresses, to locate prepaid meters (and thus register clients on their database), even in the most labyrinth-like neighborhoods; and, if need be, special meters that discourage electricity theft can be employed, although sometimes without much success. In sum, Maputo's spatial and socio-economic 'informality' is inscribed in the design and operation of the prepaid electricity system. It engages with this 'informality' in a 'problemsolving' way, seeking to work with it, managing it without addressing its underlying structural origins (see Baptista, 2015a). Yet, the new 'formal' prepaid electricity system is not without problems. For it to remain operational it requires constant work of maintenance and repair.

\subsection{Credelec maintenance and repair: Everyday re-assemblage of a socio-technical system}

Keeping the Credelec prepaid system operational entails a range of activities that may not be perceived as what the work of electricity infrastructure maintenance and repair is about. Within its organizational structure, EDM does have technical departments dedicated exclusively to the more traditional work of maintenance and repair - i.e. dealing with broken lines, restoring blackouts, or replacing faulty meters. But when clients' access to the service relies on acquiring electricity credit before they consume it, then the activity of selling prepaid tokens becomes one of the key issues in the overall reliability and stability of the electricity system. In other words, the processes involved in Credelec token sales and consumption also require their own forms of maintenance and repair. At first instance, one would presume that prepayment technology simplified this work. But the shift to prepayment engendered new problems and tensions with Maputo's 'informality' that demand everyday attention if Credelec is to operate altogether. As a way of illustration, I turn now to the issues of fraud prevention and control - particularly theft of electricity and theft of sales revenues.

Prevention against electricity theft is one of the key activities of EDM's operation and maintenance services. The introduction of prepayment did not reduce the need for this, simply changed the processes of theft prevention. Central to this work is Credelec's digital system of client data management. Every time a client buys a prepaid token, the purchase is logged on the system's servers. A meter that has not been topped up in a while (usually ninety days, in EDM's estimation) is a good indicator of an instance of electricity theft. Therefore, Maputo is crisscrossed everyday by teams of EDM auditors searching for the 'non-consuming' meters. Their work is key to maintaining Credelec's 'normal' order of things. 
In my fieldwork with the auditors, I was able to observe their pragmatic (and at times arbitrary) decision-making towards both finding the meters and addressing each (potential) theft case. Often times it was really difficult to find a meter amidst various households in neighborhoods with limited physical access. Auditors were left scrambling for strategies to find 'non-consuming' meters in these occasions. A few times, the search returned a meter that looked like it was being bypassed, but the auditor could not make a complete and reliable assessment if this was the case. In such situations, the auditor would base its decision on recording the case as an instance of theft based on a in situ judgment of the household's means to pay a fine, or on the extent to which the people in the house had addressed them (the auditor) respectfully or not. In one particular instance, when a young man just disappeared when we arrived at his house, the auditor felt no qualms in disconnecting the household and applying a fee. The search for a 'non-consuming' meter did not always return a thief, however. Often the meters were in households who have a house in Maputo, but live elsewhere, including in South Africa. Other times still, auditors could not find the nonconsuming meters altogether, despite the auditors' persistence and best efforts. A maintenance team may have replaced a faulty meter and not logged it off the system appropriately. A meter may have belonged to a failed business owner who has since set shop in a different place. In these occasions, the meter may have been moved elsewhere without EDM's knowledge. Overall, finding non-consuming prepaid meters requires the auditor to go deep into the fabric of the city and engage directly with the livelihoods of clients. It requires them to make pragmatic judgments that draw on their embodied experiences with clients and the city's built environment, i.e. with the city's 'informality'.

Theft does not pertain to clients alone; it can take place at the designated shops that sell Credelec tokens. Initially, electricity tokens were sold at EDM shops only, but these were in a small number and mostly located within the area of the cidade. To expand the sales network to the subúrbios, EDM resorted to outsourcing Credelec sales to private business owners and entrepreneurs. These shops are usually located in areas critical to the community: petrol stations, pharmacies, stores, at major road intersections, or areas of large footfall within neighborhoods. While conveniently located, these service points have been the target of robberies. In interviews with sales assistant, I learned that many had been held at gunpoint or beaten up to provide access to sales proceedings. Sometimes the robbery was said to be an inside job, led with the collaboration of shop operators, managers or owners. Other times, owners would tap into the revenue themselves, later being unable to return it to EDM. In other instances, operators tried to swindle small sums at a time, by using a glitch in the sales system. In response, shop owners had to adopt themselves some strategies of 'repair' to prevent the sales systems from breakdown. Many shops started hiring their own security guards, while others adopted 'armored' contraptions for the shop windows and doors in the hope of keeping thieves at bay. Sales assistants organized to leave the premises with the guard or their friends and coworkers, in an attempt at maintaining their safety. Some days it worked, other days it did not. The work of maintaining and repairing the sales system is as much precarious as it is endless.

The unanticipated possibilities for shop-based theft led EDM to implement a number of pragmatic management strategies to safeguard revenue - another form of maintenance and repair strategy. Using a digital retailer management system, it is possible for EDM staff to access, in real time, all transactions that individual sales assistants are conducting at each Credelec shop. The utility can know at the end of a day, week, or month how much each shop made in sales and how much it is owed back by each shop. Alongside this retailer management system, EDM introduced a daily procedure for collecting and keeping track of revenue. Twice a 
day, Credelec shops were visited by a delegate from a local bank to verify the accounting on the sales and this money was collected by a security service to handover the proceedings to the bank. Once a week, a designated EDM staff visited the shops, verified the books and collected written records of bank transactions. This paperwork was then passed on to the local EDM accounting department, which verified that paper records matched the digital records on the retailer management system. This was a laborious process that was not bullet proof, but one that allowed EDM to keep Credelec going on an everyday basis. ${ }^{5}$

In the end, the new 'formal' prepaid electricity system engendered new ways for EDM to engage with certain aspects of Maputo's informality. At the same time, it raised other unanticipated issues that required new strategies of maintenance and repair for the Credelec token sales and its consumption by households. These may not be seen as the traditional work of reconnecting broken lines or replacing faulty devices that comes to mind when thinking of maintenance and repair. Yet, without these various strategies, the Credelec system would be disrupted, reconfigured, and ultimately risk breakdown. As such, it was the re-assemblage of this socio-technical system that kept the prepaid electricity service going - a service always in the making.

\section{Conclusion}

There is now a growing acknowledgement of the 'untamable' nature of cities (Allen et al., 2016), despite the longstanding efforts of modernist urban planning in the rationalization of space and urban life. The realization is not lost on electricity utilities in African cities (and elsewhere in the global South), to whom the 'modern infrastructural ideal' of an integrated network remains the key aspiration for how electricity access should be provided to its clients. Confronted with socio-economic conditions of poverty and 'unruly' urban environments, many utilities are deploying mediating technologies, such as prepaid meters, in a bid to enhance service delivery in ways that allow them to address the challenges of 'informality'. Yet, a key issue for securing the service delivery lies in the constant work of maintenance and repair that safe keeps the integrity of the electricity network in the first place, not just in situations of breakdown.

Drawing on a socio-technical approach to infrastructures, this article explored how utilities engage with 'informality' in the provision of 'formal' services. The article's contribution is three-fold. First, by seeing infrastructures as relationally co-constituted with the urban environment in which they operate, the article foregrounded how utilities implicate the spatial and socio-economic dimensions of 'informality' in the design, delivery, and maintenance and repair of the 'formal' electricity network. Second, by directing empirical attention to the endless everyday work of maintenance and repair, the article highlighted the pragmatic (and at times random) practices that sustain and continuously produce and reproduce infrastructures in cities. This complements ongoing empirical and theoretical work on contextspecific, situated solutions to service delivery in cities of the global South. Moreover, this focus on maintenance and repair may be a helpful contribution to development and donor

5 More recently, EDM outsourced the sales of Credelec tokens to three 'super dealers' - private companies that pay EDM upfront for a bulk amount of Credelec revenue and then resell it to clients for a small profit margin. This has raised other unanticipated problems that EDM is tackling with other strategies of maintenance and repair. Due to limitations of space, I cannot go into further detail. 
communities, for whom conversations on service delivery seem to be reduced to the provision of a connection alone. Finally, by focusing on infrastructure maintenance and repair, the article offered an understanding of service delivery as a process always in the making and infrastructures as always 'precarious achievements'.

Understood in this way, it is untenable to maintain that 'formal', integrated infrastructure networks (as opposed to off-grid, hybrid, or 'informal' solutions) are the 'normal' state of affairs. If infrastructures are 'precarious achievements', then the is difficult to sustain arguments that 'formal' infrastructures are preferable over 'informal' ones on the grounds that the former is a stable, seamlessly integrated system and the latter a provisional, makeshift and unreliable arrangement. 'Formal' infrastructures are as much 'precarious' or 'provisional' as 'informal' infrastructures. Insofar utilities (and policymakers alike) prefer (or desire) 'formal' infrastructures probably reveals more about their interest in exerting control over service users than about the intrinsic material/aesthetic value of 'formal' infrastructures. Utilities are bound to engage in context-specific ways with urban life and the fabric of urban areas whether of an 'informal' or otherwise nature.

Despite the persistent desirability, in principle, of the 'formal' 'modern infrastructural ideal' in cities of the global South, in practice, utilities often adopt a diversity of approaches to service delivery, maintenance and repair that engage directly with the 'informality' of the social and built environments they operate in. The article thus offers the community of urban studies and urban practitioners, whether in Africa or elsewhere, a critical appreciation for the pragmatic, persistent, and endless everyday work of maintenance and repair utilities must engage in governing their infrastructure networks. Without such work, providing universal access to an electricity connection may be possible, but there may be darkness still when people switch the light on.

\section{Acknowledgements}

I would like to begin by thanking Michele Acuto and Cecilia Dinardi for the invitation to present at the Workshop A Culture of Informality for City Leadership, held in London on 11 May 2015. The fruitful discussions at the workshop helped shape the discussions presented in this article. I would also like to thank the Editors of the special issue and the three anonymous referees who provided such helpful and thought-provoking comments. My think on electricity infrastructures and urban development in Mozambique has been shaped through various conversations with Lucy Baker, Vanesa Cástan Broto, Joshua Kirchner, Luís Lage, Susana Neves Alves, Sue Parnell, and Shaun Smith. Data used in this article was collected with the support of Oxford's Department for Continuing Education Research Fund, Oxford's John Fell Fund Research Grant (Ref. 141/127), and a GCRF/British Academy Sustainable Development Programme grant (Ref. GF160020). The author has no conflict of interests to declare. 


\section{References}

Ahlers R, Cleaver F, Rusca M and Schwartz K (2014) Informal space in the urban waterscape: Disaggregation and co-production of water services. Water Alternatives 7(1): 1-14.

Akrich M (1992) The De-Scription of Technical Objects. In: Bijker WE and Law J (eds) Shaping Technology/Building Society: Studies in Sociotechnical Change. Cambridge, MA: MIT Press, pp. 205-224.

Alda-Vidal C, Kooy M and Rusca M (2018) Mapping operation and maintenance: An everyday urbanism analysis of inequalities within piped water supply in Lilongwe, Malawi. Urban Geography 39(1): 104-121.

Allen A, Lampis A and Swilling M (eds) (2016) Untamed Urbanisms. Abingdon, UK: Routledge.

Anand N (2012) Municipal disconnect: On abject water and its urban infrastructures. Ethnography 13(4): 487-509.

Anand N (2015) Leaky states: Water audits, ignorance, and the politics of infrastructure. Public Culture 27(2 76): 305-330.

Baptista I (2015a) Prepaid electricity in Maputo, Mozambique: Challenges for African urban planning. In: Silva CN (ed) Urban Planning in Lusophone African Countries. Surrey, UK: Ashgate, pp. 225-237.

Baptista I (2015b) 'We live on estimates': Everyday practices of prepaid electricity and the urban condition in Maputo, Mozambique. International Journal of Urban and Regional Research 39(5): 1004-1019.

Baptista I (2016) Maputo: Fluid flows of power and electricity - Prepayment as mediator of state-society relationships. In: Luque-Ayala A and Silver J (eds) Energy, Power and Protest on the Urban Grid: Geographies of the Electric City. Abingdon, UK: Routledge, pp. 112-131.

Baptista I and Plananska J (2017) The landscape of energy initiatives in sub-Saharan Africa: Going for systemic change or reinforcing the status quo? Energy Policy 110(November): 1-8.

Barnes J (2017) States of maintenance: Power, politics, and Egypt's irrigation infrastructure. Environment and Planning D 35(1): 146-164.

Berg BL (2004) Qualitative Research Methods for the Social Sciences (5th Edition). Boston, MA: Pearson Education Limited.

Bertelsen BE, Tvedten $I$ and Roque S (2014) Engaging, transcending and subverting dichotomies: Discursive dynamics of Maputo's urban space. Urban Studies 51(3): 27522769.

Bezuidenhoudt SJ, Galatis KN and Johnson PA (1996) Standardisation of prepayment systems in South Africa, 1993-1996: A systems approach. 8th International Conference on Metering and Tariffs for Energy Supply, 3 July 1996 (Conf. Pub. No. 426, pp. 94-97). Brighton, UK.

Bridge G, Bouzarovski S, Bradshaw M and Eyre N (2013) Geographies of energy transition: Space, place and the low-carbon economy. Energy Policy 53: 331-340.

Bromley R (1978) Introduction -- the urban informal sector: Why is it worth discussing? World Development 6(9-10): 1031-1198.

Callon M (2012) Society in the Making: The Study of Technology as a Tool for Sociological Analysis. In: Bijker WE, Hughes TP and Pinch TJ (eds) The Social Construction of Technological Systems: New Directions in the Sociology and History of Technology (Anniversary Edition). Cambridge, MA: The MIT Press, pp. 77-97. 
Castán Broto V and Bulkeley H (2013) Maintaining climate change experiments: Urban Political Ecology and the everyday reconfiguration of urban infrastructure. International Journal of Urban and Regional Research 37(6): 1934-1948.

Castells M and Portes A (1989) World Underneath: The Origins, Dynamics, and Effects of the Informal Economy. In: Portes A, Castells M and Benton LA (eds) The Informal Economy: Studies in Advanced and Less Developed Countries. Baltimore, MD: The Johns Hopkins University Press, pp. 11-37.

Coutard O (2008) Placing splintering urbanism: Introduction. Geoforum 39(6): 1815-1820.

Coutard $O$ and Rutherford J (eds) (2016) Beyond the Networked City: Infrastrtucture Reconfigurations and Urban Change in the North and South. London, UK: Routledge.

Criqui L (2015) Infrastructure urbanism: Roadmaps for servicing unplanned urbanisation in emerging cities. Habitat International 47(June): 93-102.

Criqui L and Zérah M-H (2015) Lost in transition? Comparing strategies of electricity companies in Delhi. Energy Policy 78: 179-188.

Denis J and Pontille D (2015) Material ordering and the care of things. Science, Technology, \& Human Values 40(3): 338-367.

Domínguez Rubio F (2016) On the discrepancy between objects and things: An ecological approach. Journal of Material Culture 21(1): 59-86.

EDM (2017) Relatório Anual de Estatística / Statistical Annual Report 2015. Maputo, Moçambique: EDM, Electricidade de Moçambique.

Furlong K (2010) Small technologies, big change: Rethinking infrastructure through STS and Geography. Progress in Human Geography 35(4): 1-23.

Furlong K (2014) STS beyond the "modern infrastructure ideal": Extending theory by engaging with infrastructure challenges in the South. Technology in Society 38: 139-147.

Ghertner DA (2012) Nuisance talk and the propriety of property: Middle class discourses of a slum-free Delhi. Antipode 44(4): 1161-1187.

Gilbert A (2007) The return of the slum: Does language matter? International Journal of Urban and Regional Research 31(4): 697-713.

Gooday GJN (2004) The Morals of Measurement: Accuracy, Irony, and Trust in Late Victorian Electrical Practice. Cambridge, UK: Cambridge University Press.

Graham S and Marvin S (2001) Splintering Urbanism: Networked Infrastructures, Technological Mobilities, and the Urban Condition. London, UK: Routledge.

Graham S and Thrift N (2007) Out of order: Understanding repair and maintenance. Theory, Culture \& Society 24(3): 1-25.

Hall M and Young T (1997) Confronting Leviathan: Mozambique Since Independence. London, UK: C. Hurst \& Co.

Hansen KT and Vaa M (eds) (2004) Reconsidering Informality: Perspectives from Urban Africa. Uppsala, Sweden: The Nordic Africa Institute.

Hart K (1973) Informal income opportunities and urban employment in Ghana. The Journal of Modern African Studies 11(1): 61-89.

Hughes TP (2012) The Evolution of Large Technological Systems. In: Bijker WE, Hughes TP and Pinch TJ (eds) The Social Construction of Technological Systems: New Directions in the Sociology and History of Technology (Anniversary Edition). Cambridge, MA: MIT Press, pp. 45-76.

ISA-PM (1972) Relatório da Inspecção Ordinária aos Serviços Municipalizados de Água e Electricidade da Câmara Municipal de Lourenço Marques pelo Inspector Administrativo Raúl Ribeiro dos Santos Delgado e Silva -- 1972 (1. Volume). Lourenço Marques, Moçambique: Inspecção dos Serviços Administrativos, Província de Moçambique. 
Isaacman A and Isaacman B (2013) Dams, Displacement, and the Delusion of Development: Cahora Bassa and its Legacies in Mozambique, 1965-2007. Athens, OH: Ohio University Press.

Jackson SJ (2014) Rethinking Repair. In: Gillespie T, Boczkowski PJ and Foot KA (eds) Media technologies: Essays on communication, materiality, and society. Cambridge, MA: The MIT Press, pp. 221-239.

Jaglin S (2008) Differentiating networked services in Cape Town: Echoes of splintering urbanism? Geoforum 39(6): 1897-1906.

Jaglin S (2014) Regulating Service Delivery in Southern Cities: Rethinking Urban Heterogeneity. In: Parnell S and Oldfield S (eds) The Routlege Handbook of Cities of the Global South. London, UK: Routledge, pp. 434-447.

Jaglin S (2016) Is the Network Challenged by the Pragmatic Turn in African Cities? Urban Transition and Hybrid Delivery Configurations. In: Coutard $\mathrm{O}$ and Rutherford J (eds) Beyond the Networked City: Infrastructure Reconfigurations and Urban Change in the North and South. London, UK: Routledge, pp. 182-202.

Jenkins P (2012) Home Space: Context Report (Research Programme 'Home Space in African Cities', funded by the Danish Research Council for Innovation 2009-2011). Copenhagen, Denmark: The Royal Danish Academy of Fine Arts, School of Architecture, Department of Human Settlements.

Kamete AY (2013) Missing the point? Urban planning and the normalisation of 'pathological' spaces in southern Africa. Transactions of the Institute of British Geographers 38(4): 639-651.

Luque-Ayala A and Marvin S (2016) The maintenance of urban circulation: An operational logic of infrastructural control. Environment and Planning D 34(2): 191-208.

McFarlane C (2012) Rethinking informality: Politics, crisis, and the city. Planning Theory \& Practice 13(1): 89-108.

McFarlane C, Desai R and Graham S (2014) Informal urban sanitation: Everyday life, poverty, and comparison. Annals of the Association of American Geographers 104(5): 989-1011.

McFarlane C and Waibel M (eds) (2012) Urban Informalities: Reflections on the Formal and Informal. Farnham, UK: Ashgate.

Mendes MC (1985) Maputo antes da Independência: Geografia de uma cidade colonial. Memórias do Instituto de Investigação Tropical 68.

Mitlin D (2008) With and beyond the state: Co-production as a route to political influence, power and transformation for grassroots organizations. Environment and Urbanization 20(2): 339-360.

Monstadt J and Schramm S (2017) Toward the networked city? Translating technological ideals and planning models in water and sanitation systems in Dar es Salaam. International Journal of Urban and Regional Research 41(1): 104-125.

Morton D (2013) From racial discrimination to class segregation in postcolonial urban Mozambique. In: Twine FW and Gardener B (eds) Geographies of Privilege. New York, NY: Routledge, pp. 231-261.

Morton D (2015) Age of Concrete: Housing and the Imagination in Mozambique's Capital, c. 1950 to Recent Times. Department of History. Minneapolis, MN: University of Minnesota.

Nielsen M (2011) Inverse governmentality: The paradoxical production of peri-urban planning in Maputo, Mozambique. Critique of Anthropology 31(4): 329-358.

Payne G (1977) Urban Housing in the Third World. London, UK: Leonard Hill. 
Pilo' $F$ (2017) A socio - technical perspective to the right to the city: Regularizing electricity access in Rio de Janeiro's Favelas. International Journal of Urban and Regional Research 41(3): 396-413.

Roy A (2005) Urban informality: Towards and epistemology of planning. Journal of the American Planning Association 71(2): 147-158.

Roy A (2011) Slumdog cities: Rethinking subaltern urbanism. International Journal of Urban and Regional Research 35(2): 223-238.

Roy A and AlSayyad N (eds) (2004) Urban Informality: Transnational Perspectives from the Middle East, Latin America, and South Asia. Lanham, MD: Lexington Books.

Shove E and Walker G (2014) What is energy for? Social practice and energy demand. Theory, Culture \& Society 31(5): 41-58.

Silver J (2014) Incremental infrastructures: Material improvisation and social collaboration across post-colonial Accra. Urban Geography 35(6): 788-804.

Sovacool BK and Dworkin MH (2015) Energy justice: Conceptual insights and practical applications. Applied Energy 142(March): 435-444.

Star SL (1999) The ethnography of infrastructure. American Behavioral Scientist 43(3): 377-391.

Strebel I (2011) The living building: Towards a geography of maintenance work. Social \& Cultural Geography 12(3).

Turner JFC (1978) Housing in three dimensions: Terms of reference for the housing question redefined. World Development 6(9-10): 1135-1145.

UN-HABITAT (2017) New Urban Agenda. New York, NY: United Nations.

UPP (1994) Crescimento da População Urbana e Problemas da Urbanização da Cidade de Maputo. Maputo, Moçambique: Unidade de População e Planificação, Direcção Nacional de Estatística, Comissão Nacional do Plano, República de Moçambique.

Ureta S (2014) Normalizing Transantiago: On the challenges (and limits) of repairing infrastructures. Social Studies of Science 44(3): 368-392.

Varley A (2013) Postcolonialising informality? Environment and Planning D 31(1): 4-22.

von Schnitzler A (2013) Traveling technologies: Infrastructure, ethical regimes, and the materiality of politics in South Africa. Cultural Anthropology 28(4): 670-693.

Winner L (1980) Do artifacts have politics? Daedalus 109(1): 121-136. 